\title{
THE USE OF INFORMATION GAP TECHNIQUE TO IMPROVE SPEAKING SKILL
}

\author{
Ranti Harvi Rahimi \\ Sultan Agung Islamic University \\ ranti@yahoo.com
}

\begin{abstract}
The final project was about the use of information gap technique to improve speaking skill. The objective of this study was to find out whether Information Gap technique was effective to improve students' speaking skill or not. A quasi experimental research design was used in this study. The population of this study was the eleventh graders of MAN 2 Semarang in the academic year 2014/2015 with the number of population around 210 students. Non-equivalent groups' pretest-posttest design was used in this study. Two classes were taken as the samples with around 60 students. The data were collected by using several activities. They were pre-test, treatment, and post-test. The result of this study shows that the pretest average of experimental class was 45.81 while the pretest average of control class was 42.12. After giving treatment for four meetings the posttest average of experimental class was 70.76 and while the posttest average control class was 49.48. The result of the analysis showed that there was a significant difference. It was supported by t-test result, the significant difference in the result of posttest between control and experimental class was $0.00<0.05$. It means that the use of Information Gap technique in teaching speaking was better than the conventional method. It could be concluded that $H_{1}$ was accepted that the use of Information Gap Technique was effective to improve students' speaking skill.
\end{abstract}

Keywords: Information Gap technique, conventional method, students' speaking skill

\section{INTRODUCTION}

Language is one of the important tools that people use to communicate with each other. With language, they can express their idea, feelings, experiences and also their mind about things that happen around them. It also helps them to socialize and interact with other people. One of the wide spread used of languages is English. English has become one of the outstanding languages for most of the people around the world. English is not only used in big cities but also in small villages of many countries in this world whether as their first or second language. 
Basically learning English can also increase the capability of Indonesian people to compete in international scope, to have better intelligence, and to get more communication skills so that at the end they will be able to get a better living. In Indonesia, English has been taught from kindergarten to university as a foreign language either compulsory or local subject.

Richards and Renandya (2002: 204) state that speaking in a foreign language is difficult for foreign language learners because the effectiveness of oral communication requires the ability to use the language appropriately in social interaction. It means that not all of Indonesian people can speak or use this language as their daily language. In studying English, there are four skills that must be mastered by students; they are speaking, listening, reading and writing. Genc (2007: 6) says that when people learn a language, there are four skills that we need for complete communication. When we learn our native language, we usually learn listening first, then speaking, and then followed by reading, and finally writing.

Speaking is one of those skills that are more practical in learning English because it is a productive skill. Students do not only learn it theoretically but they have to practice it more often.This condition has the students actively practice speaking English to make a better understanding and at the end to improve the English education quality in Indonesia. It can be added that the use of poor techniques and lack of medium in teaching English also creates the poor outcome for students in mastering the four skills especially in speaking.

There are many techniques to solve the problem. One of the techniques is information gap. It is a learning technique where two students or more work together in which each student answers to some kind of a problem or a question. Harmer (2007: 223) states that an information gap activity is an activity where learners are missing the information they need to complete a task and need to talk to each other to find it.

Based on the reason above, this study wants to examine the information gap technique in senior high school students as one of the successful ways in teaching speaking for students. This way can force the students to speak as long as they can explain more about their intention. Directly it will train their pronunciation and learning more about grammar in more fun way.

Since 2004, English has been nationally implemented as one of the subject in senior high school and at that time the government used Competency 
Based Curriculum as the improvement from 1997 curriculum. This curriculum has been welcomed by the teachers and they claimed that it will be more effectively improving the English teaching learning process than the previous curriculum. But in fact, after the government stated that Indonesia would use Educational Unit Level Curriculum in 2006 still there was no enhancement on how to intensify English language teaching in the classroom especially in senior high school.However since English is still a foreign language in Indonesia, the consequences of teaching it as a foreign language is rather difficult than teaching English as a second language like in other countries such as Malaysia and Singapore. According to Paul (2007:1):

English as a foreign language refers to English language learning which is studied by students in a country where English is not a native language. Meanwhile English as a second language refers to English language learning which is studied by students in a country where English is the native language.

As one of the central elements of communication, speaking needs special attention and instruction in an EFL context like the one in Indonesia. Considering its status as a foreign language in Indonesia, not so many people use it in their day-to-day communication. In spite of the fact that more Indonesians use English in their daily life, many people consider that English instruction is a failure in this country (Renandya, 2004:115). In reality, as the world and the technology is changing fastly otherwise the human resources in Indonesia become a central issue that need to develop their ability to communicate internationally as the important quality of the country.

\section{Information Gap Technique}

Some experts have discussed the advantages of applying information gap activities in teaching speaking. Hess (2001: 3) states:

Information gap activities can provide a comprehensive feedback from the learners, such as a wide diversity of opinions, references, and values, many different experiences and styles of learning. Then, she also adds that information gap activities can foster a learner-autonomous learning style.

It can be concluded that information gap is the communicative practice which two pairs of students have the information which they must connect or relate to the other in order to fill in the gaps. The teacher can ask the students to work in pairs, later teacher can give a form, dialogues or pictures that each of 
them has some missing parts which need to be completed by changing information.

Based on that condition, students in the classroom have their own part or job to give the missing information that belongs to the other students. Hopefully with these effective activities that happen in the classroom.

\section{METHODS}

This study used experimental research design which was included in quantitative method. Based on Gay and Airasian (2000: 8), quantitative method of research is based on the collection and analysis of numerical data, usually obtain from questionnaires, tests, checklist, and other paper and pencil instrument. Based on Arikunto (2006:125), experimental design is the way to look for the cause and effect relation between two factors.

In experimental design there were three kinds of design; pre-experimental design, true experimental design and quasi experimental design. This study would use quasi experimental design because it was impossible to do randomization. Quasi experimental design is available to the writer to provide adequate control of sources of invalidity when it is not possible to randomly assign participants to groups (Arikunto, 2006:123).

There were two groups which would be involved in this study; an experimental and the control group. An experimental group would receive the treatment while the control group would not receive the treatment. According to Cohen and Manion (2007:199) the designed could be presented as:

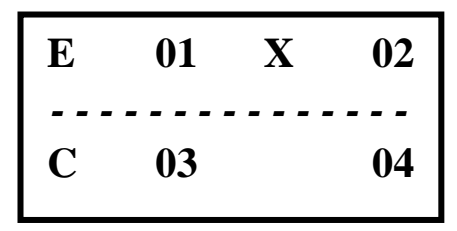

Which:

E : Experimental group

C : Control group

01 : Pretest for the experimental group

02 : Posttest for the experimental group

03 : Pretest for the control group

04 : Posttest for the control group 
$\mathrm{X} \quad$ : Treatment for experimental group using information gap technique Subject of the Study

The population of this study would be the eleventh graders of MAN 2 Semarang in the academic year 2014/2015. The number of the population of the eleventh graders was around 210 students. This research used purposive sampling that in purposive sampling, also referred to as judgment sampling, the researcher selects a sample based on his or her experience or knowledge of the group to be sampled (Gay and Airasian, 2000: 138). Based on that statement, this research took two classes; A (XI Science 1), and B (XI Science 2) as the sample of this research. Each of class consists of at least 30 students. Class A was an experimental group and class B was a control group.

Instrument of the Study

Instrument is a device that is use to collect the data and make the work become easy to process (Arikunto, 2006: 160). As the instrument, this research used tape recorder and a test. Tape recorder used to record students' voices when they worked in pairs to answer the questions. There were two types of test: Pre-test and Post-test. In both experimental and control class the students would have a pre-test to find out the students' achievement in speaking. Both groups had the same questions and they had it before the treatment. In the other hand, post-test was conducted after treatment. Both experimental and control groups would be given a post-test with the same questions.

\section{FINDINGS}

The research was designed to find out whether information gap technique could help students to improve their speaking skill or not. In order support this research, the test was used to get the data. The feature of SPSS 16.0 software was used to analyze the data in order to find out the significant difference between pre-test and post-test in the experimental class also pre-test andpost-test in the control class. There were three activities in this study: pretest, treatment, and post-test. 
Data Collection of Experimental Class

This pre-test was conducted at the first meeting on September $18^{\text {th }}, 2014$ at 08.30 a.m. The total number of students was 37 students. There were 12 situations, each sheets had a different fill in the blank picture. Then they were asked to practice it with their partners. The topic was past tense. It required 90 minutes to administer it.

Table 1 The Pre-Test Result in Experimental Class

\begin{tabular}{cc}
\hline Score & Number of Students \\
\hline Excellent : $91-100$ & 0 \\
Very Good : $81-90$ & 1 \\
Good : $71-80$ & 2 \\
Fair : $61-70$ & 3 \\
Poor : $51-60$ & 9 \\
Very Poor : $0-50$ & 22 \\
\hline Total & $\mathbf{3 7}$ \\
\hline
\end{tabular}

While, the post-test was conducted on September, 30th, 2014 at 08.30 a.m. Each time took 90 minutes. The total number of students was 37 students. The post-test was conduct after the treatment done. To assess the test, the students were given some sheets with the same topic but different pictures. Level of the topic was the same as pre-test. It required 90 minutes to administer it.

Table 2 The Post-Test Result in Experimental Class

\begin{tabular}{cc}
\hline Score & Number of Students \\
\hline Excellent: $91-100$ & 0 \\
Very Good: $81-90$ & 2 \\
Good: $71-80$ & 19 \\
Fair: $61-70$ & 12 \\
Poor: $51-60$ & 4 \\
Very Poor: $0-50$ & 0 \\
\hline Total & $\mathbf{3 7}$ \\
\hline
\end{tabular}


Data Collection of Control Class

This test was conducted at the first meeting on September 19th, 2014 at 08.30 a.m. The total number of students was 40 students. There were 12 situations, each sheets had a different fill in the blank picture. Then they were asked to practice it with their partners. The topic was past tense. It required 90 minutes to administer it.

Table 3 The Pre-test Result in Control Class

\begin{tabular}{cc}
\hline Score & Number of Students \\
\hline Excellent: $91-100$ & 0 \\
Very Good: $81-90$ & 0 \\
Good: $71-80$ & 0 \\
Fair: $61-70$ & 2 \\
Poor: $51-60$ & 6 \\
Very Poor: $0-50$ & 32 \\
\hline Total & $\mathbf{4 0}$ \\
\hline
\end{tabular}

The post-test was conducted on October, 1st, 2014 at 08.30 a.m. The total number of students was 40 students. To assess the test, the students were given some sheets with the same topic but different pictures. Level of the topic was the same as pre-test. It required 90 minutes to administer it.

Table 4 The Post-Test Result in Control Class

\begin{tabular}{cc}
\hline Score & Number of Students \\
\hline Excellent: $91-100$ & 0 \\
Very Good: $81-90$ & 0 \\
Good: $71-80$ & 0 \\
Fair: $61-70$ & 4 \\
Poor: $51-60$ & 11 \\
Very Poor: $0-50$ & 25 \\
\hline Total & $\mathbf{4 0}$ \\
\hline
\end{tabular}


Table 5 Comparison of Pre-Test Result in Control and Experimental Class

\begin{tabular}{|c|c|c|c|c|c|c|c|c|}
\hline \multirow[t]{2}{*}{ Group } & \multirow[t]{2}{*}{$\mathrm{N}$} & \multirow[t]{2}{*}{ Mean } & \multirow{2}{*}{$\begin{array}{c}\text { Std. } \\
\text { Deviation }\end{array}$} & \multicolumn{3}{|c|}{$\begin{array}{c}\text { Levene's Test for } \\
\text { Equality of } \\
\text { Variances }\end{array}$} & \multicolumn{2}{|c|}{ T-test for Equality of Means } \\
\hline & & & & $\mathrm{F}$ & & Sig. & $\begin{array}{l}\text { Sig. }(2- \\
\text { tailed) }\end{array}$ & Mean difference \\
\hline Control & $\begin{array}{l}4 \\
0 \\
\end{array}$ & 42.12 & 11.516 & \multirow{2}{*}{$\begin{array}{r}6.0 \\
02\end{array}$} & \multirow{2}{*}{\multicolumn{2}{|c|}{.017}} & \multirow{2}{*}{.253} & \multirow{2}{*}{-3.686} \\
\hline $\begin{array}{c}\text { Experimenta } \\
1\end{array}$ & $\begin{array}{l}3 \\
7\end{array}$ & 45.81 & 16.336 & & & & & \\
\hline
\end{tabular}

Sig.(2-tailed) $\leq 0.05$ = Significance difference

As the table 5 shows, there were two groups: control and experimental class. Control class consists of 40 students and experimental class consists of 37 students. The mean of pre-test for the control class was 42.12 and for the experimental class was 45.81. The standard deviation was 11.516 for control class and 16.336 for experimental class. Sig.(2-tailed) was .253 and mean difference was -3.686. Sig was .017. From the Leven's Test for Equality of Variances indicates homogeneity $\mathrm{F}=6.002$.

Table 6 Comparison of Post-test Result in Control and Experimental Class

\begin{tabular}{|c|c|c|c|c|c|c|c|}
\hline \multirow{2}{*}{ Group } & \multirow{2}{*}{$\mathbf{N}$} & \multirow{2}{*}{ Mean } & \multirow{2}{*}{$\begin{array}{c}\text { Std. } \\
\text { Deviation }\end{array}$} & \multicolumn{2}{|c|}{$\begin{array}{c}\text { Levene's Test for } \\
\text { Equality of } \\
\text { Variances }\end{array}$} & \multicolumn{2}{|c|}{$\begin{array}{l}\text { T-test for } \\
\text { Equality of } \\
\text { Means }\end{array}$} \\
\hline & & & & $\mathbf{F}$ & Sig. & $\begin{array}{l}\text { Sig.(2- } \\
\text { tailed) }\end{array}$ & $\begin{array}{l}\text { Mean } \\
\text { differ } \\
\text { ence }\end{array}$ \\
\hline Control & 40 & 49.48 & 9.923 & \multirow[b]{2}{*}{1.947} & \multirow[b]{2}{*}{.167} & \multirow[b]{2}{*}{.000} & \multirow{2}{*}{$\begin{array}{l}- \\
21.28 \\
2\end{array}$} \\
\hline Experimental & 37 & 70.76 & 7.025 & & & & \\
\hline
\end{tabular}

Sig. (2-tailed) $\leq 0.05=$ Significance difference

As the table 6 shows that, there were two groups: control and experimental class. Control class consists of 40 students and experimental class consists of 37 students. The mean of post-test was 49.48 for control class and 70.76for experimental class. The standard deviation was 9.923 for control class and 7.025 for experimental class. Sig. (2-tailed) was .000 and mean difference 21.282 Sig was .167. From the Leven's Test for Equality of Variances indicates homogeneity $\mathrm{F}=1.947$. 
Table 7 Comparison of Pre-test and Post-test Result in Control Class

\begin{tabular}{lccccccc}
\hline Group & $\mathbf{N}$ & Mean & $\begin{array}{c}\text { Std. } \\
\text { Deviation }\end{array}$ & & \multicolumn{2}{c}{$\begin{array}{c}\text { Levene's Test for } \\
\text { Equality of } \\
\text { Variances }\end{array}$} & \multicolumn{2}{c}{$\begin{array}{c}\text { T-test for } \\
\text { Equality of Means }\end{array}$} \\
\cline { 5 - 8 } & & & & F & Sig. & Sig.(2-tailed) & $\begin{array}{c}\text { Mean } \\
\text { difference }\end{array}$ \\
\hline Pre-Test & 40 & 42.12 & 11.516 & \multirow{2}{*}{2.778} & .100 & .000 & -7.350 \\
\hline Post-Test & 40 & 49.48 & 9.923 & & & &
\end{tabular}

The table 7 shows that, there were two tests, they were pre-test and posttest. Every test had 37 students. The mean of pre-test in control class was 42.12 and post-test in control class was 49.48. The standard deviation of pre-test was 11.516 and standard deviation of post-test was 9.923. Sig. (2-tailed) was 0.000 and mean difference was -7.350. Sig was 0.100. From the Leven's Test for Equality of Variances indicates homogeneity $F=2.778$.

Table 8

Comparison of Pre-test and Post-test Result in Experimental Class

\begin{tabular}{|c|c|c|c|c|c|c|c|}
\hline \multirow[b]{2}{*}{ Group } & \multirow[b]{2}{*}{$\mathbf{N}$} & \multirow[b]{2}{*}{ Mean } & \multirow{2}{*}{$\begin{array}{c}\text { Std. } \\
\text { Deviation }\end{array}$} & \multicolumn{2}{|c|}{$\begin{array}{c}\text { Levene's Test for } \\
\text { Equality of Variances }\end{array}$} & \multicolumn{2}{|c|}{$\begin{array}{c}\text { T-test for } \\
\text { Equality of Means }\end{array}$} \\
\hline & & & & $\mathbf{F}$ & Sig. & $\begin{array}{c}\text { Sig. } \\
\text { (2-tailed) }\end{array}$ & $\begin{array}{c}\text { Mean } \\
\text { differenc } \\
e\end{array}$ \\
\hline Pre-Test & $\begin{array}{l}3 \\
7\end{array}$ & 45.81 & 16.336 & \multirow{2}{*}{$\begin{array}{c}27 . \\
81 \\
6\end{array}$} & \multirow{2}{*}{.000} & \multirow{2}{*}{.000} & \multirow{2}{*}{-24.946} \\
\hline Post-Test & $\begin{array}{l}3 \\
7\end{array}$ & 70.76 & 7.025 & & & & \\
\hline
\end{tabular}

Sig. (2-tailed) $\leqq 0.05$ = Significance difference

The table 8 shows that, there were two tests, they were pre-test and posttest. Every test had 36 students. The mean of pre-test in experimental class was 45.81 and post-test in experimental class was 70.76. The standard deviation of pre-test was 16.336 and standard deviation of post-test was 7.025. Sig. 2-tailed was .000 and mean difference was -24.946. Sig was .000. From the Leven's Test for Equality of Variances indicates homogeneity $F=27.816$. 


\section{CONCLUSION}

It could be concluded that the use of Information Gap technique could improve the students' speaking skill. Based on the result of the study, there was a significant difference between the result of the post-test in the control class and experimental class. Therefore, the calculation of post-test the average of experimental group was 70.76, and the average of control group was 49.48. It means that the students' score who used the Information Gap technique in learning speaking (experimental class) was higher than the students' score who learned with conventional method (control class). It was proven from the calculation which shows that $t$-value in equal variance is $t=-10.782$ and Sig. (2tailed) $=0.000$. It means that there was a significant difference in speaking skill between the students who were taught by Information Gap technique and those who were not. From the result of this study, it was expected that this study could provide a meaningful contribution to open a new perspective and expected to be useful for English teacher of senior high school in teaching speaking skill.

With regard to the use of information gap technique, this study would like to provide some suggestions that may bring benefit to improve speaking skill especially for the teacher and to the students in general, and the other researchers.

a. For teachers, this study can be other resource of important information especially for English teachers so that they will have a various strategies to improve student's speaking skill.

b. For students, they are expected to be able to construct their ideas, and also their concept in speaking by using information gap.They also can be more creative to express their idea, also easier to follow the teaching learning process and absorb the lessons. They will have a lot of times to discuss with others to improve their ability in speaking.

c. For further researcher, this study can give them an informative method and experience in teaching speaking by using information gap, and directly develop their deeper knowledge. 


\section{REFERENCES}

Arikunto, Suharsimi. 2010. Prosedur Penelitian: Suatu Pendekatan Praktik. (Fourteenth ed.). Jakarta: PT Rineka Cipta.

Cohen, Louis, and Manion. 2007. Research Methods in Education (6thed.). New York: Routledge.

Gay and Airasian. 2000. Educational Research: Competencies for Analysis and Application. New Jersey: Merrill Prentice Hall.

Genc, B. 2007. An Analysis of Communication Strategies Employed by TurkishSpeakers of English. Doctoral Dissertation, The Institute of Social Sciences, Department of English Language Teaching, Cukurova University, Adana: Turkey.

Harmer, Jeremy. 2007. How to Teach English (New Edition). London: Longman Group Ltd.

Hess, N. 2001.Teaching Large Multilevel Classes. Cambridge: Cambridge University Press.

Paul, David. 2007. Teaching English to Children in Asia. Hiroshima: Pearson Longman.

Renandya, W. A. 2004. Indonesia. In. H. W. Kam\& R. Y. L. Wong (eds), Language Policies and Language Education: The Impact in East Asian Countries in the Next Decade. Singapore: Eastern University Press.

Richards, J, C. Renandya, W.A. 2002. Methodology in Language Teaching: An Anthology of Current Practice. Cambridge: Cambridge University Press. 